\title{
The Function of The System "Education Plus Upbringing" In the Context of The Purpose of a Person
}

\author{
Kvinray Raevich Bayanov ${ }^{1 *}$ \\ ${ }^{1}$ Glazov State Pedagogical Institute named after V.G. Korolenko, Department of History and Social \\ and Humanitarian Disciplines, Glazov, Russia
}

\begin{abstract}
This paper deals with the definition of the "Education plus upbringing" system in the context of the purpose of the human being. The paper draws a demarcation line between the concepts of EDUCATION (in the sense of 'to educate', 'to form') and UPBRINGING ('the development of qualities', 'the establishment of qualities'). This distinction has a clear quantified character. While education implies influencing a person through knowledge to form a scientific world view, the process of upbringing involves influencing them through images and examples to instill certain qualities that are in demand by the society and the state. The author demonstrates a semantic connection between the terms 'education' and 'upbringing' thought the concept of perception. The paper defines the purpose of life as an integral biosystem and the place and the role of the human being and ethnic groups within it. Based on this methodological message, the author outlines the purpose of the "Education plus upbringing" system.
\end{abstract}

\section{Introduction}

At all times, human thought has been distinguished by one universal feature, namely the desire to form an "Education plus upbringing" system which would be able to develop knowledge and necessary skills and pass them to the next generation to establish its future. It should be noted that this problem currently attracts the interest of many scholars around the world [1-11]. A distinctive feature of this system in the modern era of globalism is its crisis. Therefore, it is advisable to start the analysis with an assessment of the causes of this crisis.

The crisis of the "Education plus upbringing" system has a multidimensional character, including the introduction of market relations into education and upbringing, loss of focus on personal development, difficulties in determining the ideals of the individual and society, dehumanization of society, lack of a clear demarcation line between educational activities and upbringing, seeing comfort as the highest life value due to a sharp deterioration in the environment, multiple definitions that give vague ideas about education and upbringing. Finally, the problems in the "Education plus upbringing" system are not investigated

\footnotetext{
*Corresponding author: kvinray@mail.ru
} 
concerning the purpose of the human being. This paper is dedicated to this particular circle of problems.

\section{Methods}

In this research, we used the following list of principles. The principle of consistency: to see the system in everything. The principle of evolution: the main form of being is not rest but movement, emergence. The principle of complementarity: the ability to describe the processes of socio-cultural dynamics using various models. The principle of the Universal Semantic Code (USC): the ability to reveal the hidden meaning of words and thereby explain the mechanisms of life organization.

These methods of analysis allowed solving the aforementioned problem.

\section{Analysis and solution of the problem}

Distinguishing and comprehending the function of education and upbringing is NOT possible without understanding the purpose of LIFE as an integral biosystem and the role of the human being and different ethnic groups within life in the historical process.

This question, the question of the purpose of life as an integral biosystem and the role of the human being and different ethnic groups in the historical process gets a clear solution on the panel of the concept of the USC, which "is a hidden binary core of the universal human language, composed of two languages, Russian and Arabic (RA)" [12]. In other words, the concept of USC explains and states that there is a hidden binary core of the universal human language, which forms a semantic field that controls living objects through their names. By revealing this mechanism, we reveal the secret of the organization of life.

Studies on the semantic side of life confirm that life as the terrestrial biomass in the form of an integral biosystem, like any living object, saves itself by reproducing itself. However, for life, the instrument of self-reproduction is the HEAD of a person. It must be understood that in this capacity a person is not so much a subject but a tool (and there is nothing to be done about it). It seems that life does not need subjects, especially non-intelligent ones, as it is the subject itself (subject going back to the Arabic bugyat 'having a goal'). The main condition and indicator of the maturity of this tool is the fullness of the head with the right semantic units, which are elementary units of meaning. As for individual biological objects from an individual cell to ethnic formations, the meaning of their existence is to correspond to verbal programs executed with the language code of RA [13].

Thus, we conclude that a person in the life system is not a subject, but a tool. The meaning of their life is expressed in the fact that once awakened, they become appropriate to their purpose, i.e. to reproduce the system called life through their head and the semantic units.

Taking into account the indicated methodological premises, we need, on the one hand, to clarify the semantics of the terms 'education' and 'upbringing' with the establishment of a demarcation line between them, and on the other, to study educational and upbringing-related activities for the human being and human history.

The dictionary of the Russian language interprets EDUCATION as "obtaining systematic knowledge and skills, training, enlightenment" [14].

Meanwhile, etymologically the Russian word for education (obrazovanie) goes back to obraz ('image'), شكل shakl in Arabic, which serves as a basis for شكل shakkal 'to establish, to form', where the Russian word shkola ('school') comes from. Thus, education as a term is synonymous with the school.

Any educational system suffers from the disadvantage of accustoming the student to the idea that he or she lives in a world of meaningless words. Thus, it puts the child to sleep. Yet 
no one asks more questions about the reasons for everything than a child. This suggests that a child from birth has the gland of curiosity given to him or her by the Lord, which teachers take out at a young age. It is enough, however, to give a correct and understandable etymology of words for everything secret to become clear and for all the lies to fall off like dry mud. Therefore, no reforms in school education are required. It is only necessary to stop clogging the children's brains with incomprehensible terminology. Then they will find out for themselves what is false and what is true. We need to show them that words are not used against logic and common sense, but are employed in full agreement with them. Then the children's consciousness will be in harmony with itself too. All secrets will be revealed. Everything hidden will become clear. The rest will take care of itself. The main obstacle to awakening the officials in education who see the purpose of education in constant reform is the introduction of innovations with tolerance. Eugenics being in fashion now, they are introducing various crazy methods into school education, based on which they sort children into those who will work in agriculture and industry, in the service sector, and the ones who will be in charge of things.

The awakening depends mainly on how soon the teachers will understand the perniciousness of nonsense. We must be aware that any unmotivated word is a psychotronic generator that induces the mind to sleep. Especially if this word is given an illogical explanation. The mind gets used to absurdism, and, of course, does not ask questions about the reasons for this or that phenomenon. According to etymologists, the word compass comes from Italian where it means 'to measure with steps'. This nonsense is printed in textbooks. Such an absurdity does not remain without consequences. The sleeping mind understands what is familiar. It doesn't even occur to it to ask what the connection is between the steps and the compass.

The compass, "a device for determining the countries of the world, the magnetized arrow of which always points to the North", is related in meaning and sound to the words lakmus ('litmus') and the Arabic اموس k la: mu:s 'dictionary', i.e. 'determinant'. The doubling of bilabial sounds (MP, MB) is a characteristic feature of Romance languages with numerous examples. For instance, Ar. أمر amr 'order' is reflected as imperative in those languages, etc.

A correct system of upbringing should correspond to the formation of the right education system. Well-established definitions of upbringing indicate that it is a process of nurturing (a child): "influencing the spiritual and physical development, giving education, teaching the rules of behavior" [15].

VOSPITANIE ('upbringing') is a native Russian word with a clear inner structure that is derived from the word pitanie ('nutrition'), cf. the use of kormit ('to feed') and vskarmlivat ('to nurture') in the sense of 'to bring (somebody) up'. In a broad sense, it can be understood as 'preparation of qualities'.

The semantic connection between education and upbringing is established through PERCEPTION as a process in which knowledge is mastered in the educational process, and in the sphere of upbringing, the qualities of a person's character that are in demand by society, such as patriotism, perseverance, professionalism, etc. The Russian word for PERCEPTION, vospriyatie, with all the apparent motivation (the addition of the prefix vos- and the root word priyatie meaning 'acceptance') comes from the Ar. عرف ta'arruf (in reverse reading) 'identification' + şä sifa 'quality'. Thus, it means 'the identification of the qualities'.

If education as an impact on the physical development of a child is carried out by militarypatriotic and sports games, then spiritual development involves the influence of literature, theater, and art to instill and nurture the necessary qualities, such as patriotism, perseverance, professionalism.

Thus, if education involves influencing a person through knowledge and thus forms a scientific picture of the world, then the process of upbringing is expressed in influence 
through images and examples to cultivate certain qualities of a person that are in demand by society and the state at this historical stage and might be in demand in the future.

A characteristic feature at the present stage is that against the background of globalization, education and upbringing are subject to significant correction [16-18].

Specifically, the processes of awakening and dumbing-down children and adults are developing in the framework of globalization. If the awakening is mainly related to the explanation of incomprehensible terminology, then the dumbing-down is manifested in the destruction of the educational system in favor of the interests of transnational companies (TNCs) and transnational banks (TNBs) under the banner of renewal. A clear confirmation of this is given in the "Crisis of Democracy" report where the democracy itself, a highly educated society, and a high degree of political participation of the masses in government are called a democracy threat for the Capitalist elite [19-21].

This explains the strengthening of the postmodern orientation of the modern global educational system [22].

Postmodernism is a very effective means of fighting for power over society. The modern postmodern education and upbringing inevitably lead the system to a civilizational impasse, since it does not provide a more adequate scientific world view. It now offers a choice of several answers, one of which is correct. In this format of teaching, the world view disappears. The system gets these new society members as non-professionals who can neither recognize problems nor solve them.

\section{Conclusion}

The solution to this problem has led us to the conclusion that the purpose of the "Education plus upbringing" system is to awaken and encourage people to fulfill their purpose. However, for an integral biosystem of life, the human head acts as an instrument of its reproduction. The main condition and indicator of the maturity of this tool is the fullness of the head with the right semantic units, which are elementary units of meaning. In this context, the person acts not as a subject, but as a tool in the integral biosystem of life. The meaning of the person's life is expressed in the fact that once awakened, they become appropriate to their purpose, i.e. to reproduce the system called life through their head and the semantic units.

\section{References}

1. E. Niechwiej-Szwedo, K. Meier, L. Christian, M. Nouredanesh, J. Tung, P. Bryden, Dev. Psychobiol. 62(3), 353-367 (2020)

2. T.A. Beck, Theory \& Research in Social Education 41 1-32 (2013)

3. K. Charmaz, The search for meanings - grounded theory, in J.A. Smith, R. Harré, L. Van Lagenhove (Eds.), Rethinking methods in psychology (Sage Publications, London 1996)

4. C.A. Grant, E. Zwier, Multicultural Perspectives 13(4), 181-188 (2011)

5. J. Owens, Sociology of Education, 89(3), 236-258 (2016)

6. M.A. Martin, Social Science Research 41(1), 33-47 (2012)

7. G. Kraaykamp, N. Notten, Research in Social Stratification and Mobility 45, 63-71 (2016)

8. A. Björklund, M. Jäntti, Labour Econ. 19 465-474 (2012)

9. A.E. Clark, A. Lepinteur, J. Econ. Behav. Organ. 166, 107-124 (2019)

10. F. Cunha, J.J. Heckman, S.M. Schennach, Econometrica 78, 883-931 (2010) 
11. E. Grönqvist, B. Öckert, J. Vlachos, J. Hum. Resour. 52, 887-918 (2017)

12. N.N. Vashkevich, Behind seven seals. Secrets of the origin of the language. Bible symbols. Russian phraseology (Publishing House "White Alves", Moscow, 2004)

13. N.N. Vashkevich, World Periodic Law. Introduction to semantic logic (Publisher S. Landyshev, Moscow, 2010)

14. S.I. Ozhegov, N.Yu. Shvedova, Explanatory dictionary of the Russian language (ITI Technologies, Moscow, 2006)

15. Brockhaus and Efron Encyclopedic Dictionary Electronic version. Available at: http://www.brocgaus.ru/

16. K.R. Bayanov, Philosophical and methodological foundations of forecasting socionatural dynamics: abstract of dissertation for the degree of Doctor of Philosophy (Moscow State Academy of Business Administration, Moscow, 2011)

17. N.O. Ismailov, Philosophy and culture 3(75), 350-361 (2014)

18. N.O. Ismailov, Sociology of power 8, 95-103 (2009)

19. N.O. Ismailov, Sociology of power 7, 136-144 (2009)

20. N.O. Ismailov, National Security nota bene 3, 445-453 (2014)

21. N.O. Ismailov, Sociology of power 5, 133-139 (2009)

22. K.R. Bayanov, N.P. Pavlova, Almanac of the Center for Social Sciences and Faculty of Economics, Lomonosov Moscow State University 6(120), 222-231 (2018) 